\title{
Probe into the Diversification Reform of Graduation Design (Thesis) for Undergraduate English Majors in Independent College
}

\author{
Cheng Chen ${ }^{1,2, *}$, Xuehua Ren ${ }^{1}$, Liang Tang ${ }^{1}$, You Li ${ }^{1}$ \\ ${ }^{1}$ Chengdu College, \\ University of Electronic Science and Technology of China, \\ Chengdu, China \\ ${ }^{2}$ Key Laboratory for NeuroInformation of Ministry of Education, Center for Information in Medicine, \\ University of Electronic Science and Technology of China, \\ Chengdu, China \\ *Correspondence: happycc886@126.com
}

\begin{abstract}
Graduation design (thesis) for undergraduate English majors has long been suffering from various problems. Some colleges and universities have taken improvement measures and gained positive results, but the situation has not been fundamentally changed. The current study is based on the diversification reform of graduation design (thesis) for undergraduate English majors in Chengdu College of University of Electronic Science and Technology of China to probe into the mode and approach to improve the quality of graduation design (thesis). The reform recruited new forms (project development and research report), refined requirements and standards, encouraged students to finish the graduation design in a team approach, and combined the design with scientific research projects. The afterward questionnaire showed the diversification reform was successful. Students obtained great improvement in various abilities, and teachers' evaluation of this reform was positive, providing an instructive and lightening guidance for the future graduation design (thesis) work for undergraduate English majors in independent colleges.
\end{abstract}

Keywords-Undergraduate English majors; graduation design (thesis); problems; diversification reform

\section{INTRODUCTION}

The General Office of Ministry of Education of China has issued Notice of Strengthening the Graduation Design (Thesis) of General Institutes of Higher Education in 2004 and pointed out that graduation design (thesis) is an important teaching link to achieve the cultivation objectives. It plays an irreplaceable role in such aspects as cultivating college students to explore the truth, intensifying their social consciousness, carrying out basic training in scientific research among them, improving their comprehensive practice ability and quality, and so on. It is a combination of education, production and social practice, and serves as an important practical link to cultivate college students' innovative ability, practical ability and entrepreneurial spirit. At the same time, the quality of the graduation design (thesis) provides an important basis for measuring the level of teaching, the

This work was supported by the fund from the Education Department of Sichuan Province (16SB0360), and the fund from the Dean's Office of Chengdu College, University of Electronic Science and Technology of China ([2016]26). graduation of students and the authentication of degree qualification [1].

Teaching Syllabus for English Majors of General Higher Education Colleges and Universities (hereinafter referred to as Teaching Syllabus for English Majors) also points out the requirements for graduation design (thesis) for undergraduate English majors by explicitly stipulating that the graduation design (thesis) is implemented in the form of graduation thesis. Teaching Syllabus for English Majors stipulates that graduation thesis is an important way to examine students' comprehensive ability and evaluate their academic performance. The graduation thesis should be written in English, with a length of 3,000 to 5,000 words. The text should be smooth, students should be clear-headed, and the thesis should have substantial contents, with certain independent opinions. When evaluating the thesis, besides the language competence, both the independent opinions and the innovative consciousness should be taken into consideration. Colleges and universities should strengthen the guidance and review of graduation thesis for students so as to be really helpful for them instead of being merely formalistic [2].

It is observed that Ministry of Education of China and the English Section of Foreign Language Teaching Advisory Board under the Ministry of Education both attach great importance to the graduation design (thesis) for undergraduate students. This is because graduation design (thesis) is the last systematic training for college students before they step into the society and enter workplace, which serves as an important stage to improve the comprehensive quality of students. However, it is also found that Teaching Syllabus for English Majors has some limitations in the requirements for the graduation thesis, such as, the requirement for the form is incomprehensive, the understanding of the meaning of graduation design (thesis) is insufficient, the cognition of the educational function of graduation design (thesis) is inadequate, and so on; therefore, some specific problems are found during the actual operation process. 


\section{CURRENT PROBLEMS}

College graduates have been keeping rapid growing since college expansion in 1999. The development of China's higher education has experienced a rapid transformation from elite education to mass education. Therefore, China's undergraduate education is always under great pressure, and the society as well as the colleges and universities themselves pay close attention to the employment of graduates; thus, graduation design (thesis) just takes a back seat although it is highly related to students' employment [3]. The problems found during the actual operation process are as follows.

\section{A. Students' Poor Attitudes, Insufficient Abilities, and Limited Energy}

Many students believe that graduation design (thesis) has little to do with their future work, so they hold less serious attitudes and barely slip by. Usually, the academic foundation of students, especially those in independent colleges, is weak. They lack academic training and scientific research consciousness. Meanwhile, they sustain great employment pressure; so they are busy taking internship and finding jobs, which severely decentralize their energy and attention. As a result, the final graduation design (thesis) is loose in structure, shallow in argumentation, poor in language quality, and weak in academic expression. It is merely a patchwork, lacking creativity. What's worse is that some students just copy from others or even ask some other people to write for them, causing academic misconduct [4].

\section{B. Insufficient Teaching Staff and Teachers' Limited Energy and Ability}

It is widely known that teachers in colleges and universities are in shortage. They usually undertake heavy teaching and scientific research tasks, and suffer great pressure of professional title promotion. Therefore, teachers often feel tired of dealing with many issues simultaneously, thus it is difficult for them to conduct high-quality and adequate guidance on students. Topics provided by teachers are usually old-fashioned, difficult to promote students' autonomy and creativity. Some teachers even lack professional knowledge, scientific research ability, and sense of responsibility; so it is hard for them to provide adequate and effective guidance. As a result, students know little about the real significance of graduation design (thesis), the academic norms, and writing skills. Finally, they unsurprisingly fail to produce a highquality graduation design (thesis), but just try hard to pass.

\section{Less Diverse Topics and Distant from Major Reality and Social Demand}

At present, most English departments require students to write research papers on linguistics and literature, which lacks diversity in form and the topics usually fall short of the realistic demand. For English majors in independent colleges, their knowledge of linguistics and literature is inadequate, and they are more interested in equipping themselves with practical skills demanded by the society. Topics on linguistics and literature seem unreachable and impracticable for them. Most English departments pay insufficient attention to students' practical ability in listening, speaking, reading, writing and translating, leave a small chance for students to use their language skills and professional knowledge to engage in creative tasks, and neglect students' desire to improve practical abilities and better serve the society. So, it is very difficult to stimulate students' interest and creativity.

\section{Management Department's More Attention to Students' Employment, Leaving the Management Merely Formalistic}

The management department has formulated detailed rules and regulations to guide graduation design work; however, under the pressure from society and school development, the school also attaches great importance to students employment. It is quite often that the management department just pursues the specification of graduation design document work, paying relatively less attention to the graduation design content, the writing process, and some tough writing problems [5]. The current graduation design (thesis) evaluation also lacks scientific and objective quality evaluation system, so there is high arbitrariness in performance evaluation and the evaluation result can hardly reflect the requirements of the Teaching Syllabus for English Majors.

\section{E. Insufficient Support in Policy and Facilities}

Not many English departments offer academic writing courses in the nationwide, providing students with insufficient training in writing knowledge and skills. What's more, independent colleges are also restricted by place, funds support, books and reference materials, so it is difficult for them to provide effective guarantee for graduation design (thesis). In addition, the current situation lacks corresponding reward and incentive mechanisms, causing low participation initiative among teachers and students.

\section{CURRENT MEASURES TO IMPROVE THE QUALITY OF GRADUATION DESIGN (THESIS) FOR UNDERGRADUATES}

From the aforementioned problems, due to the students level, faculty strength, support strength, support system and other aspects of constraints, the graduation design (thesis) for undergraduate English majors is in conflict with students' internship, employment and so on. Some measures are needed to change the present situation so as to improve the effect of graduation design (thesis) and the quality of talent cultivation. Some colleges have tried to change students' attitudes toward graduation design, improve the quality of guidance given by teachers, improve the quality of topic selection, develop more forms of graduation design, strengthen supervision and management, improve the review mechanism, and so on. Although some results and experiences have been achieved, these attempts have not fundamentally influenced the view of talent cultivation and its result. For independent colleges restricted by many factors, how to find a suitable and feasible mode under the background of creativity, innovation and serving the local economic and social development and on the basis of the existing reference measures needs deep thinking and active exploration [6]. 
IV. DIVERSIFICATION REFORM OF GRADUATION DESIGN (THESIS) FOR UNDERGRADUATE ENGLISH MAJORS IN CHENGDU

COLLEGE OF UNIVERSITY OF ELECTRONIC SCIENCE AND TeChNOlogy of China (Chengdu COLlege of UESTC)

\section{A. Reform Contents and Characteristics}

Aiming at the current problems existing in the graduation design (thesis) for undergraduate English majors in independent colleges and based on the current measures as well as the achieved results and experience, Chengdu College of UESTC put forward diversification reform of graduation design (thesis) for undergraduate English majors. The reform mainly included the following aspects:

- The form, topic selection and results were diversified. This reform has changed the traditional single form of graduation thesis and introduced two new forms, namely, project development and research report. The form of project development was subdivided into literary work translation project, film and television work dubbing project, teaching materials or handouts collation and development project, text corpus construction project, and audio and video corpus construction project. The diversification of form brought about the diversity of topic. Both the teachers and students had relatively larger degree of freedom to select the topic. The motivation of both sides was obviously stimulated and applicability was more stressed on during topic selection. Thus, the results of the graduation design work were diversified. Compared with the less innovative and uninspiring paper produced by the traditional single form of graduation thesis, this reform has been proved quite effective.

- Requirements and standards were refined. At first, we revised the graduation design (thesis) management manual. Taking the requirements made by the Teaching Syllabus for English Majors for graduation design (thesis) for undergraduate students as reference, in combination with the actual situation of students in Chengdu College of UESTC, we formulated relevant requirements and standards for each category of the project and research report, including the work load and checking stages and standards. While refining the requirements and standards, we also tried to ensure appropriate difficulty and strong operability for students. Since this was the first practice, various problems emerged in the implementation process. English teaching and research section of the college and all teachers participating in the graduation design guidance carried out prompt discussion and provided timely and effective solutions to the problems students encountered and raised. Almost simultaneously, relevant instructions were made for future reference. At the later period when students were writing reports, useful notes and reference outline were given to the students to help them develop a clear logic and structure and follow uniform format requirements.

- Students were encouraged to carry out graduation design in a team approach. This approach was a highlight of this reform and was highly welcomed and respected by both the teachers and the students. It can be proved by the fact that among all the 65 students, except the students who chose graduation thesis, the left 42 chose to work in a team on the new forms of project development and research report, accounting for about $2 / 3$ of the total; while among all the 15 teachers, 10 chose this approach, accounting for $2 / 3$ of the total. After the division of work load and responsibility, students were encouraged and required to cooperate with team members, carry out discussion periodically, and help each other in almost all aspects like material collection and analysis, translation, dubbing, report writing, grammar checking, and so on. Feedback from teachers and students suggested that teamwork made it possible for them to complete larger project together, which improved the practicability and value of the graduation project. Also, team work approach reduced the difficulty of the project, which improved students' self-confidence and enthusiasm. Moreover, a stronger friendship was built among teachers and students, which helped students to develop their future life and career.

- There was a combination of graduation design and scientific research project. Fortunately we got policy and financial support from two scientific research projects, one on translation talents cultivation, and the other on corpus development. Books, software and other materials were bought to aid the scientific research and graduation design work. Students were supported to visit some companies and organizations. Teachers and students have actively carried out a number of discussion on such issues as relevant regulations, specific standards, report form, content itself, and so on. The combination was beneficial for not only improving the quality of graduation design, but also facilitating the smooth completion of the scientific research projects. Therefore, the approach of combing graduation design with scientific research project deserves promotion and popularization.

\section{B. Reform Effects}

After the graduation design work, a questionnaire survey was conducted on both the 65 students and 15 teachers who participated in the graduation design. For students, we mainly focused on the forms and categories of their graduation design, the finishing style (in a personal or team way), the work load, the significance and value they felt, and the degree of improvement of various abilities. For teachers, we mainly focused on the still existing problems in the reform process and the corresponding improvement measures.

According to students' feedback, 23 students selected traditional graduation thesis, accounting for $35 \%$ of the total; 36 students selected project development, accounting for $56 \%$; and 6 students selected research report, accounting for $9 \%$. It can be seen that project development was very popular with students. Students reflected that project development is of greater significance and value, but also a larger work load. Except the students who selected graduation thesis, students 
who selected the other two forms of graduation design finished their work in a team approach.

In terms of the degree of improvement of various abilities, we rated on a five-point scale from very small to very large. According to students' feedback, as for the improvement of the ability to collect, collate and analyze data, among the students who selected project development, $80.56 \%$ believed that they have achieved a large degree of improvement, among the students who selected research report, $66.67 \%$ believed so, while among the students who selected graduation thesis, $43.38 \%$ believed that they just perceived a general degree of improvement. As for students' mastery of basic theory, knowledge and skills of their major, as well as the improvement of the ability to comprehensively use the learned knowledge to analyze and solve practical problems, the result was similar. As for the improvement of the ability of writing and innovation, students who selected graduation thesis and project development believed that they have experienced a comparatively larger degree of improvement than those who selected research report. As for the improvement of the ability of logical thinking, most students who selected project development believed they have gained a large degree of improvement, while most students who selected graduation thesis and research report believed that they just felt a general degree of improvement. As for the improvement of teamwork ability, students who selected project development and research report believed that they have gained a large degree of improvement, while most students who selected graduation thesis believed that they just felt a general degree of improvement. Overall, students who selected project development believed that they have felt a large degree of improvement of all kinds of abilities, while students who selected graduation thesis believed that they just felt a general degree of improvement. Students who selected research report felt quite similarly with those who selected project development; however, since not many students selected research report in this reform, their feedback was only taken as a minor reference. Finally, according to the above analysis, we can come to the conclusion that our diversification reform of graduation design (thesis) has achieved remarkable results.

Perhaps the possible reasons of this successful reform were that the topics were much more interesting, attractive, practical and operable, and the forms were more flexible and diverse, so students had more autonomy. Also, the new mode stimulated students' interest, efforts and achievements, and the results were more meaningful and valuable, which would be more instructive to the future graduation design work as well as more helpful to students' future employment.

Teachers' feedback also proved that this diversification reform was successful. However, there were of course some problems. One is that many teachers believed that the work load of the two new forms was very large, so it took a large amount of time and effort from both the teachers and the students to ensure the quality of graduation design. Another is that some detail problems needed to be addressed for the management department. What's more, the review mechanism was still imperfect and less scientific, and the formation of relevant rules and standards should be done well in advance or follow up steadily during the process of graduation design. Although there were still problems, generally speaking, teachers' feedback and evaluation of this graduation design reform were positive.

\section{CONCLUSION}

Graduation design (thesis) is a comprehensive practice teaching link of talent cultivation concerning China's higher education, which is a teaching process of learning, practice, exploration and innovation [7]. Graduation design (thesis) for undergraduate English majors can, to a large extent, reflect students' original opinions, knowledge level, comprehensive application ability, innovative practice ability, scientific writing ability and so on. By implementing graduation design, independent colleges are supposed to improve the teaching links, and thus improve the quality of college graduates so as to further promote the virtuous circle of higher education. Based on the target of application-oriented talent cultivation, and from the perspective of serving local economic and social development, independent colleges should select topics that are beneficial for students in accordance with the local schools and social facts and in combination with the knowledge and characteristics of students and teachers. The mode, approach and results of the diversification reform of graduation design (thesis) for undergraduate English majors in Chengdu College of UESTC are instructive and enlightening. If we are more open-minded to introduce in some new modes like schoolenterprise, school-government and some other cooperation, and combine entrepreneurship, innovation, revenue generation, employment and serving local development together, it will be easier and more ideal for the talent cultivation to meet the demand of the enterprises and the society [6].

\section{REFERENCES}

[1] The General Office of Ministry of Education of China, "Notice of Strengthening the Graduation Design (Thesis) of General Institutes of Higher Education," (In Chinese) Beijing, no. 14, April 2004.

[2] English Section of Foreign Language Teaching Advisory Board under the Ministry of Education, Teaching Syllabus for English Majors of General Higher Education Colleges and Universities, (In Chinese) Beijing: Foreign Language Teaching and Research Press, April 2000.

[3] Z. Aihua and W. Minghong, "Discussion on the problems and improvement plan of the graduation design (thesis)," (In Chinese) Journal of Architectural Education in Institutions of Higher Learning. Chongqing, vol. 25, pp. 167-169, Feb. 2016.

[4] W. Chongyi, "Strengthen the guidance of graduation thesis, and improve students' comprehensive quality," (In Chinese) Foreign Language Education, Beijing, vol. 25, pp. 73-76, Nov. 2004.

[5] C. Junyue and L. Zhipan, "Practical considerations in diversifying graduation design (thesis) for English majors," (In Chinese) Foreign Language Research In Northeast Asia. Liaoning, vol. 8, pp. 54-48, March 2017.

[6] Y. Jiarui, "Research on the way to improve the quality of graduation design for design majors in local universities," (In Chinese) Journal of Baoshan University. Yunnan, vol. 36, pp. 104-108, April 2017.

[7] N. Ruifeng, T. Wenting, L. Zhenlin, and Z. Zhongming, "Thinking and practice of cultivating students' innovative abilities in graduation design," (In Chinese) Experimental Technology and Management. Beijing, vol. 32, pp. 23-25, April 2015. 